Reviu Akuntansi dan Bisnis Indonesia, Vol. 2 No. 2, Hlm: 186-196, Desember 2018

Website: http://journal.umy.ac.id/index.php/rab

\title{
Analisis Faktor-Faktor yang Mempengaruhi Pengungkapan Internet Financial Reporting di Indonesia dan Malaysia (Studi Empiris pada Perusahaan Manufaktur yang Terdaftar di Bursa Efek Indonesia dan Bursa Malaysia Tahun 2014-2016)
}

Yusrina Ilmawati; Arum Indrasari
Program Studi Akuntansi Univeritas Muhammadiyah Yogyakarta.

\begin{tabular}{l}
\hline I N F O A R T I K E L \\
\hline Kata Kunci: \\
Internet Financial \\
Reporting, Firm Size, \\
Profitability, Liquidity, \\
Leverage, and Age of \\
Listing. \\
Jenis Artikel: \\
Penelitian Empiris \\
Correspondence: \\
arum.indrasari@umy.ac.id
\end{tabular}

\begin{abstract}
A B S T R A K
\end{abstract}
Penelitian ini bertujuan untuk menganalisis faktor-faktor yang mempengaruhi pengungkapan Internet Financial Reporting (IFR) di perusahaan manufaktur yang terdaftar di Bursa Efek Indonesia dan Bursa Efek Malaysia periode 2014-2016. Variabel yang diteliti dalam penelitian ini terdiri dari ukuran perusahaan, profitabilitas, likuiditas, leverage, dan usia listing. Penelitian ini menggunakan metode purposive sampling, diperoleh 60 perusahaan manufaktur di Indonesia dan 99 perusahaan manufaktur di Malaysia. Tes yang dilakukan meliputi: statistik deskriptif, asumsi klasik, koefisien determinasi, uji $\mathrm{F}$, regresi berganda, uji t, dan uji chow. Hasil penelitian menunjukkan bahwa ukuran perusahaan berpengaruh positif dan signifikan terhadap pengungkapan IFR di Indonesia dan Malaysia. Profitabilitas tidak mempengaruhi pengungkapan IFR, sedangkan di Malaysia pengaruh positif dan signifikan. Likuiditas tidak mempengaruhi pengungkapan IFR di Indonesia dan Malaysia, leverage tidak mempengaruhi pengungkapan IFR di Indonesia dan Malaysia. Usia listing tidak mempengaruhi pengungkapan IFR di Indonesia dan Malaysia. Ada perbedaan dalam pengungkapan IFR di Indonesia dan Malaysia. Ada perbedaan dalam ukuran perusahaan, profitabilitas, likuiditas, leverage, dan usia listing terhadap pengungkapan IFR di Indonesia dan Malaysia.

(C) 2019 RAB. Published by Universitas Muhammadiyah Yogyakarta

\section{PENDAHULUAN}

Salah satu kebutuhan yang paling penting bagi stakeholder terutama para investor adalah dibutuhkannya informasi keuangan. Informasi tersebut penting, sebab dijadikan sebagai sarana pertanggungjawaban bagi perusahaan atas dana yang telah diinvestasikan oleh para stakeholder dan juga dapat mencerminkan kondisi atas perusahaan tersebut. berbagai wilayah geografis.

Pada era globalisasi saat ini, perkembangan teknologi informasi telah mengubah cara penyebaran informasi. Jika dulu penyebaran informasi dilakukan secara tradisional, kini telah berubah semenjak adanya internet. Maka dari itu, perusahaan juga turut memanfaatkan internet sebagai salah satu media dalam menyampaikan informasi. Indonesia dan Malaysia merupakan sebuah negara berkembang yang tentunya tidak terlepas dari fenomena tersebut. Sebab, baik 
perusahaan di Indonesia maupun Malaysia dituntut untuk dapat meningkatkan informasi yang dimilki untuk memuaskan stakeholder perusahaan, termasuk para investor.

Menurut Handoko dan Fuad (2013) jika dahulu internet oleh suatu perusahaan hanya digunakan untuk menyebarkan informasi umum dan mempromosikan produk mereka saja, akan tetapi kini internet bisa juga untuk menyebarkan informasi yang berkaitan dengan keuangan suatu perusahaan yaitu melalui Internet Financial Reporting (IFR). IFR dapat didefinisikan sebagai pengungkapan informasi keuangan perusahaan melalui internet yang tercantum pada website resmi perusahaan. Pencantuman laporan keuangan pada website perusahaan akan membuat para pengguna informasi mudah dalam mengakses informasi yang akan mereka butuhkan yang berhubungan dengan suatu perusahaan

Diterapkannya IFR ini dapat digunakan sebagai upaya untuk mengurangi adanya asimetri informasi antara perusahaan dengan pihak luar. Di Indonesia, penyajian informasi melalui web tercantum dalam Peraturan Otoritas Jasa Keuangan Nomor 29/POJK.04/2016 BAB IV Pasal 15 Ayat 1 yang mewajibkan seluruh perusahan yang telah terdaftar di Bursa Efek Indonesia untuk menyajikan laporan tahunan dalam situs web masing-masing emiten atau perusahaan publik. Sedangkan di Malaysia peraturan mengenai pelaporan keuangan diatur oleh Companies Act 1965, standar akuntansi yang disetujui oleh Malaysian Accounting Dewan Standar (MASB) paragraf 9.02 (1) setiap perusahaan yang terdaftar di Bursa Malaysia harus mengungkapkan semua informasi perusahaan kepada publik yang nantinya diperlukan oleh para investor. Disahkannya peraturan tersebut, maka praktek IFR di Indonesia dan Malaysia akan semakin banyak diterapkan karena diharuskan, sehingga dapat mendorong perusahaan untuk segera menyampaikan informasi yang berhubungan dengan perusahaan kepada publik yang nantinya akan dapat mempengaruhi efek dan keputusan untuk berinvestasi dalam bursa efek. Oleh karena itu, perlu penelitian IFR yang berfokus pada manfaat dan kemudahan penggunaan IFR yang ada saat ini.

\section{TINJAUAN LITERATUR DAN PERUMUSAN HIPOTESIS}

\section{Teori Keagenan}

Agency theory menjelaskan mengenai hubungan keagenan antara principal sebagai pemilik sumber daya dengan agent sebagai pengelola sumber daya dalam suatu kontrak kerja sama (Jensen dan Meckling, 1976). Teori agensi timbul lantaran terdapat perbedaan kepentingan antara agent dan principal sehingga setiap pihak berusaha untuk mencari keuntungan sebesar-besarnya bagi diri sendiri. Pada agency theory terdapat tiga macam hubungan antara agent dan principal, yaitu: hubungan agency antara manajer dan kreditur, hubungan agency antara manajer dan pemerintah dan hubungan agency antara manajer dan pemegang saham. Hal ini berarti terdapat kecenderungan bagi manajer untuk melaporkan sesuatu dengan cara-cara tertentu dalam rangka memaksimalkan utilitas mereka dalam hal hubungannya dengan pemilik, kreditur maupun pemerintah. Praktik IFR merupakan media untuk menyampaikan informasi sebagaimana yang dikehendaki dalam kontrak keagenan.

\section{Teori Signaling}

Signalling theory menjelaskan mengenai bagaimana suatu perusahaan itu mampu memberikan sinyal kepada pihak eksternal yakni kepada pengguna laporan keuangan. Signalling theory mengemukakan mengenai investor menginginkan agar mempunyai informasi yang sama dengan informasi yang dimiliki oleh para manajer. Hal tersebut menimbulkan adanya asymetry information. Maka dari itu, untuk mengurangi asymetry information tersebut dengan memberikan sinyal kepada pihak eksternal berupa informasi keuangan positif serta bisa dipercaya, sehingga dapat mengurangi ketidakpastian yang berkaitan dengan prospek perusahaan dimasa mendatang, serta dapat meningkatkan kredibilitas dan kesuksesan suatu perusahaan tersebut. 


\section{Hubungan ukuran perusahaan dengan pengungkapan IFR di Indonesia dan Malaysia}

Besar dan kecilnya suatu ukuran perusahaan akan mempengaruhi besarnya agency cost yang harus dikeluarkan. Perusahaan yang besar diikuti dengan agency cost yang besar, Adanya praktik IFR sebagai salah satu upaya dalam menurunkan agency cost yang dikeluarkan oleh perusahaan. Penelitian terdahulu oleh Kartika dan Puspa (2013), Ramadhan (2014), Pranoto (2015) menyatakan adanya pengaruh ukuran perusahaan terhadap pengungkapan IFR. Maka dari itu, hipotesis yang dapat diturunkan sebagai berikut:

\section{$\boldsymbol{H}_{\mathrm{Ia}} \quad$ : Ukuran perusahaan berpengaruh positif terhadap pengungkapan IFR di Indonesia. \\ $\boldsymbol{H}_{l b} \quad$ : Ukuran perusahaan berpengaruh positif terhadap pengungkapan IFR di Malaysia.}

\section{Hubungan profitabilitas dengan pengungkapan IFR di Indonesia dan Malaysia}

Profitabilitas merupakan kemampuan perusahaan dalam menghasilkan laba pada periode tertentu, yang dijadikan sebagai acuan dalam menilai kinerja manajemen. Perusahaan yang memilki kinerja profitabilitas yang baik, maka akan mempublikasikan goodnews tersebut melalui praktik IFR. Selain itu melalui praktik IFR ini juga sebagai ajang untuk meningkatkan rasa kepercayaan kepada publik khususnya para investor terhadap perusahaan tersebut. Penelitian terdahulu oleh Rozak (2012), Siagian dan Ghozali (2012), Asprilia (2016) menyatakan adanya pengaruh profitabilitas terhadap pengungkapan IFR. Maka dari itu, hipotesis yang dapat diturunkan sebagai berikut:

\section{$\boldsymbol{H}_{2} \quad$ : Profitabilitas berpengaruh positif terhadap pengungkapan IFR di Indonesia. \\ $H_{2 b} \quad$ : Profitabilitas berpengaruh positif terhadap pengungkapan IFR di Malaysia.}

\section{Hubungan likuiditas dengan pengungkapan IFR di Indonesia dan Malaysia}

Likuiditas didefinisikan sebagai kemampuan perusahaan dalam melunasi kewajiban jangka pendeknya. Tingkat likuiditas perusahaan dapat mempengaruhi keputusan para investor ketika akan melakukan investasi di perusahaan tersebut. Perusahaan memiliki likuiditas yang tinggi, maka akan berhubungan dengan melakukan pelaporan keuangan yang lengkap, salah satunya melalui penerapan praktik IFR. Penelitian terdahulu oleh Prasetya dan Irwandi (2012), Handoko dan Fuad (2013) menyatakan adanya pengaruh likuiditas terhadap pengungkapan IFR. Maka dari itu, hipotesis yang dapat diturunkan sebagai berikut:

\section{$\boldsymbol{H}_{\boldsymbol{H}_{a}} \quad$ : Likuiditas berpengaruh positif terhadap pengungkapan IFR di Indonesia. \\ $\boldsymbol{H}_{s b} \quad$ : Likuiditas berpengaruh positif terhadap pengungkapan IFR di Indonesia.}

\section{Hubungan leverage dengan pengungkapan IFR di Indonesia dan Malaysia}

Leverage menunjukkan besarnya ekuitas perusahaan yang didanai oleh hutang. Semakin tinggi leverage juga menunjukkan semakin besar tingkat pendanaan perusahaan yang dibiayai oleh hutang. Semakin tinggi perusahaan melakukan hutang, akan melakukan pengungkapan informasi laporan keuangan lebih luas yakni dengan menerapkan pelaporan keuangan melalui internet atau IFR (Lestari dan Chariri, 2007). Penelitian terdahulu oleh Almilia (2008), Susanto dan Lukito 
(2015) menyatakan adanya pengaruh leverage terhadap pengungkapan IFR. Maka dari itu, hipotesis yang dapat diturunkan sebagai berikut:

\section{$\boldsymbol{H}_{\boldsymbol{\alpha}} \quad$ : Leverage berpengaruh positif terhadap pengungkapan IFR di Indonesia. \\ $H_{\star b} \quad:$ Leverage berpengaruh positif terhadap pengungkapan IFR di Malaysia.}

\section{Hubungan umur listing dengan pengungkapan IFR di Indonesia dan Malaysia}

Umur perusahaan mencerminkan seberapa lama perusahaan berdiri dan mampu bertahan serta bersaing dengan perusahaan lain. Perusahaan yang telah lama listing cenderung akan lebih transparan dalam memberikan informasi laporan keuangan perusahaan. Perusahaan yang telah lama listing dianggap lebih berpengalaman dalam mempublikasikan laporan keuangan dan mengetahui apa saja item pengungkapan yang bermanfaat bagi para penggunanya. Perusahaan yang telah lama listing juga lebih cenderung untuk mengganti metode penyampaian informasi keuangannya mengikuti kemajuan teknologi, sehingga lebih memilih untuk menyajikan laporan keuangan tahunan melalui IFR. Penelitian terdahulu oleh Alwi (2015), Alarussi dan Shamkhi (2016) menyatakan adanya pengaruh umur listing terhadap pengungkapan IFR. Maka dari itu, hipotesis yang dapat diturunkan sebagai berikut:

\section{$\boldsymbol{H}_{\boldsymbol{H a}_{2}} \quad$ : Umur listing berpengaruh positif terhadap pengungkapan IFR di Indonesia. \\ $\boldsymbol{H}_{s b} \quad$ : Umur listing berpengaruh positif terhadap pengungkapan IFR di Malaysia.}

\section{Pengungkapan IFR di Indonesia dan Malaysia}

Menurut Kartika dan Puspa (2013) sebagai perusahaan publik maka perusahaan tersebut harus dapat menyajikan informasi yang bersifat wajib maupun sukarela, baik berkaitan dengan konten dan cara penyajiannya.

Publikasi informasi yang bersifat wajib ini adalah seperti laporan keuangan tahunan yang diaudit dan laporan keuangan tengah tahunan yang tidak diaudit adalah bersifat wajib (mandatory). Maka dari itu, untuk mempublikasikan informasi keuangan perusahaan adalah melalui penerapan IFR yang dapat mempermudah pengguna informasi dalam mengakses informasi yang mereka butuhkan yang berhubungan dengan suatu perusahaan. Penelitian terdahulu oleh Susanto dan Lukito (2015), Handayani dan Almilia (2013). Maka dari itu, hipotesis yang dapat diturunkan sebagai berikut:
$\boldsymbol{H}_{6 a} \quad$ : Terdapat perbedaan pengungkapan IFR di Indonesia dan Malaysia.
$\boldsymbol{H}_{ø b} \quad$ : Terdapat perbedaan pengaruh ukuran perusahaan, profitabilitas, likuiditas, leverage, dan umur listing terhadap pengungkapan IFR di Indonesia dan Malaysia.

\section{METODE PENELITIAN}

Obyek dalam penelitian ini adalah perusahaan manufaktur yang terdaftar di Bursa Efek Indonesia (BEI) dan Bursa Malaysia pada tahun 2014-2016. Teknik pengambilan sampel menggunakan metode purposive sampling yakni sampel dipilih berdasarkan kriteria tertentu yang telah ditetapkan oleh peneliti. Kriteria-kriteria yang ditetapkan untuk pengambilan sampel dalam penelitian ini adalah sebagai berikut: 
1. Perusahaan manufaktur yang terdaftar di Bursa Efek Indonesia (BEI) dan Bursa Malaysia pada tahun 2014-2016.

2. Perusahaan yang memiliki website dapat diakses dan tidak dalam perbaikan.

3. Perusahaan yang telah mempublikasikan laporan keuangan dan annual report selama periode penelitian.

4. Perusahaan yang memiliki data-data lengkap terkait dalam penelitian.

Internet Financial Reporting (IFR) merupakan variabel dependen dalam penelitian ini. Praktik IFR dalam penelitian ini diukur menggunakan checklist 48 item, dimana kategori 1 untuk perusahaan yang pengungkapannya melalui internet dan 0 untuk perusahaan yang pengungkapannya tidak melakukan pengungkapan melalui internet Variabel ukuran perusahaan diukur dengan menggunakan logaritma natural dari total aktiva. Variabel profitabilitas diukur menggunakan Return on Equity. Variabel likuiditas diukur menggunakan Current Rasio. Variabel leverage diukur dengan menggunakan Debt to Asset Ratio. Variabel umur listing diukur menggunakan selisih antara tahun observasi laporan keuangan dengan tahun saat Initial Public Offering.

Pengujian hipotesis dilakukan dengan menggunakan analisis regresi linier berganda untuk menguji pengaruh variabel dari ukuran perusahaan, profitabilitas, likuiditas, leverage, dan umur listing terhadap pengungkapan Internet Financial Reporting (IFR). Digunakan pula uji beda t-test untuk melihat perbedaan Internet Financial Reporting (IFR) di Indonesia dan Malaysia, serta Chow test untuk menguji model regresi untuk kelompok yang digunakan dalam penelitian ini, terdapat dua kelompok yakni perusahaan manufaktur di Indonesia dan Malaysia.

\section{HASIL DAN PEMBAHASAN}

Tabel 1 Uji Parsial (Uji $t$ ) Indonesia

\begin{tabular}{|c|c|c|c|c|c|}
\hline \multirow{2}{*}{ Model } & \multicolumn{2}{|c|}{ Unstandardized Coefficients } & \multirow{2}{*}{$\begin{array}{c}\text { Standardized } \\
\text { Coefficients } \\
\text { Beta }\end{array}$} & \multirow{2}{*}{$\mathrm{t}$} & \multirow{2}{*}{ Sig. } \\
\hline & B & Std. Error & & & \\
\hline (Constant) & -1.097 & 0,314 & & $-3,489$ & 0,001 \\
\hline SIZE & 0,281 & 0,098 & 0,220 & 2,866 & 0,005 \\
\hline PROFIT & 0,132 & 0,093 & 0,109 & 1,418 & 0,158 \\
\hline LIKUID & $-0,019$ & 0,017 & $-0,108$ & $-1,151$ & 0,251 \\
\hline LEV & $-0,020$ & 0,020 & $-0,093$ & $-0,973$ & 0,332 \\
\hline LIST & $-0,029$ & 0,022 & $-0,102$ & $-.1,347$ & 0,180 \\
\hline
\end{tabular}

\section{Ukuran perusahaan terhadap pengungkapan Internet Financial Reporting}

Berdasarkan Tabel 1 menunjukkan ukuran perusahaan memiliki nilai koefisien regresi yang arahnya positif sebesar 0,281 , dengan signifikansi sebesar $0,005<$ alpha $(0,05)$ sehingga ukuran perusahaan berpengaruh positif terhadap pengungkapan IFR. Dengan demikian hipotesis pertama $\left(\mathrm{H}_{\mathrm{ta}}\right)$ yang menyatakan bahwa ukuran perusahaan berpengaruh positif terhadap pengungkapan IFR di Indonesia dinyatakan diterima.

\section{Profitabilitas terhadap pengungkapan Internet Financial Reporting}

Berdasarkan Tabel 1 menunjukkan profitabilitas memiliki nilai koefisien regresi yang arahnya positif sebesar 0,132 , dengan signifikansi sebesar 0,158 > alpha $(0,05)$ sehingga profitabilitas tidak berpengaruh terhadap pengungkapan IFR. Dengan demikian hipotesis kedua $\left(\mathrm{H}_{2}\right)$ yang menyatakan bahwa profitabilitas berpengaruh positif terhadap pengungkapan IFR di Indonesia dinyatakan ditolak.

\section{Likuiditas terhadap pengungkapan Internet Financial Reporting}


Berdasarkan Tabel 1 menunjukkan likuiditas memiliki nilai koefisien regresi yang arahnya negatif sebesar 0,019, dengan signifikansi sebesar 0,251 > alpha $(0,05)$ sehingga likuiditas tidak berpengaruh terhadap pengungkapan IFR. Dengan demikian hipotesis ketiga $\left(\mathrm{H}_{3 a}\right)$ yang menyatakan bahwa likuiditas berpengaruh positif terhadap pengungkapan IFR di Indonesia dinyatakan ditolak.

\section{Leverage terhadap pengungkapan Internet Financial Reporting}

Berdasarkan Tabel 4.17 menunjukkan leverage memiliki nilai koefisien regresi yang arahnya negatif sebesar 0,020, dengan signifikansi sebesar $0,332>$ alpha $(0,05)$ sehingga leverage tidak berpengaruh terhadap pengungkapan IFR. Dengan demikian hipotesis kempat $\left(\mathrm{H}_{\mathrm{tan}}\right)$ yang menyatakan bahwa leverage berpengaruh positif terhadap pengungkapan IFR di Indonesia dinyatakan ditolak.

\section{Umur listing terhadap pengungkapan Internet Financial Reporting}

Berdasarkan Tabel 1 menunjukkan umur listing memiliki nilai koefisien regresi yang arahnya negatif sebesar 0,029, dengan signifikansi sebesar 0,180 > alpha $(0,05)$ sehingga umur listing tidak berpengaruh terhadap pengungkapan IFR. Dengan demikian hipotesis kelima $\left(\mathrm{H}_{s_{2}}\right)$ yang menyatakan bahwa umur listing berpengaruh positif terhadap pengungkapan IFR di Indonesia dinyatakan ditolak.

Tabel 2 Uji Parsial (Uji $t$ ) Malaysia

\begin{tabular}{|c|c|c|c|c|c|}
\hline \multirow{2}{*}{ Model } & \multicolumn{2}{|c|}{ Unstandardized Coefficients } & \multirow{2}{*}{$\begin{array}{c}\text { Standardized } \\
\text { Coefficients } \\
\text { Beta }\end{array}$} & \multirow{2}{*}{$\mathrm{t}$} & \multirow{2}{*}{ Sig. } \\
\hline & B & Std. Error & & & \\
\hline (Constant) & $-1,866$ & 0,384 & & $-4,855$ & 0,000 \\
\hline SIZE & 0,500 & 0,132 & 0,230 & 3,803 & 0,000 \\
\hline PROFIT & 0,223 & 0,064 & 0,197 & 3,465 & 0,001 \\
\hline LIKUID & 0,008 & 0,010 & 0,063 & 0,871 & 0,385 \\
\hline LEV & 0,002 & 0,008 & 0,014 & 0,205 & 0,838 \\
\hline LIST & 0,022 & 0,015 & 0,082 & 1,444 & 0,150 \\
\hline
\end{tabular}

Berdasarkan pengujian pada Tabel 4.18 dapat dirumuskan model regresi sebagai berikut: IFR $=$ $1,886+0,500($ SIZE $)+0,223($ PROFIT $)+0,008($ LIKUID $)+0,002($ LEV $)+0,022($ LIST $)+\mathrm{e}$

Hasil pengujian terhadap hipotesis-hipotesis penelitian:

\section{Ukuran perusahaan terhadap pengungkapan Internet Financial Reporting}

Berdasarkan Tabel 2 menunjukkan ukuran perusahaan memiliki nilai koefisien regresi yang arahnya positif sebesar 0,500 , dengan signifikansi sebesar $0,000<$ alpha $(0,05)$ sehingga ukuran perusahaan berpengaruh positif terhadap pengungkapan IFR. Dengan demikian hipotesis pertama $\left(\mathrm{H}_{\mathrm{b}}\right)$ yang menyatakan bahwa ukuran perusahaan berpengaruh positif terhadap pengungkapan IFR di Malaysia dinyatakan diterima.

\section{Profitabilitas terhadap pengungkapan Internet Financial Reporting}

Berdasarkan Tabel 2 menunjukkan profitabilitas memiliki nilai koefisien regresi yang arahnya positif sebesar 0,223 , dengan signifikansi sebesar $0,001<$ alpha $(0,05)$ sehingga profitabilitas berpengaruh positif terhadap pengungkapan IFR. Dengan demikian hipotesis kedua $\left(\mathrm{H}_{2 \mathrm{r}}\right)$ yang menyatakan bahwa profitabilitas berpengaruh positif terhadap pengungkapan IFR di Malaysia dinyatakan diterima.

\section{Likuiditas terhadap pengungkapan Internet Financial Reporting}


Berdasarkan Tabel 2 menunjukkan likuiditas memiliki nilai koefisien regresi yang arahnya positif sebesar 0,008 , dengan signifikansi sebesar $0,385>$ alpha $(0,05)$ sehingga likuiditas tidak berpengaruh terhadap pengungkapan IFR. Dengan demikian hipotesis ketiga $\left(\mathrm{H}_{\text {sь }}\right)$ yang menyatakan bahwa likuiditas berpengaruh positif terhadap pengungkapan IFR di Malaysia dinyatakan ditolak.

\section{Leverage terhadap pengungkapan Internet Financial Reporting}

Berdasarkan Tabel 2 menunjukkan leverage memiliki nilai koefisien regresi yang arahnya positif sebesar 0,002 , dengan signifikansi sebesar $0,838>$ alpha $(0,05)$ sehingga leverage tidak berpengaruh terhadap pengungkapan IFR. Dengan demikian hipotesis kempat $\left(\mathrm{H}_{4 \mathrm{~b}}\right)$ yang menyatakan bahwa leverage berpengaruh positif terhadap pengungkapan IFR di Indonesia dinyatakan ditolak.

\section{Umur listing terhadap pengungkapan Internet Financial Reporting}

Berdasarkan Tabel 2 menunjukkan umur listing memiliki nilai koefisien regresi yang arahnya positif sebesar 0,022, dengan signifikansi sebesar $0,150>$ alpha $(0,05)$ sehingga umur listing tidak berpengaruh terhadap pengungkapan IFR. Dengan demikian hipotesis kelima $\left(\mathrm{H}_{s_{2}}\right)$ yang menyatakan bahwa umur listing berpengaruh positif terhadap pengungkapan IFR di Indonesia dinyatakan ditolak.

Tabel 3 Uji Beda $t$ Indonesia-Malaysia Independent Sample t-test

\begin{tabular}{llllll}
\hline & \multicolumn{4}{l}{ Levene's Test for Equality of } \\
& $\begin{array}{l}\text { Variances } \\
\mathrm{F}\end{array}$ & Sig. & $t$ & $\mathrm{~d}$-test for Equality of Means & Sig.(2-tailed) \\
\hline $\begin{array}{l}\text { Equal variances } \\
\text { assumed }\end{array}$ & 1,153 & 0,283 & 2,057 & 2860 & 0,040 \\
$\begin{array}{l}\text { Equal variances } \\
\text { not assumed }\end{array}$ & & & 2,097 & 2397,536 & 0,037 \\
\hline
\end{tabular}

Berdasarkan Tabel 3 didapatkan hasil bahwa nilai $\mathrm{F}$ hasil Levene's test for equality of variance pada ukuran perusahaan sebesar 1,153 dengan signifikan 0,040 karena signifikan < 0.05 maka dapat disimpulkan bahwa kedua negara tersebut (Indonesia dan Malaysia) memiliki perbedaan pengungkapan Internet Financial Reporting. Dengan demikian hipotesis keenam (H6a) yang menyatakan bahwa terdapat perbedaan pengungkapan Internet Financial Reporting antara Indonesia dan Malaysia dinyatakan diterima.

$$
\begin{aligned}
& \mathrm{F}=\frac{(\mathrm{RSSr}-\mathrm{RSSur}) / \mathrm{k}}{\mathrm{RSSur} /(\mathrm{n} 1+\mathrm{n} 2-2 \mathrm{k})} \\
& \text { RSSur }=7.466+5.507=12,973 \\
& \mathrm{RSSr}=13.322 \\
& \mathrm{n} \quad=477 \\
& \mathrm{k}=5 \\
& \mathrm{~F}_{\text {hitumg }}=2,584645 \\
& \mathbf{F}_{\text {tabel }}=2,39 \\
& \mathrm{~F}_{\text {hitumg }}>\mathrm{F}_{\text {tabel }} \\
& \mathrm{F}=\frac{(13,332-12,973) / 5}{12,973 /(467)} \\
& \mathrm{F}=\frac{71,8}{27,77944}=2,584645
\end{aligned}
$$


Hasil Chow test menunjukan bahwa nilai $\mathbf{F}$ hitung sebesar 2,58 dan $\mathbf{F}$ tabel sebesar 2,39 yang berarti pengaruh ukuran perusahaan, profitabilitas, likuiditas, leverage, dan umur listing terhadap pengungkapan Internet Financial Reporting antara Indonesia dan Malaysia memang berbeda. Dengan demikian hipotesis keenam $\left(\mathrm{H}_{65}\right)$ yang menyatakan bahwa terdapat perbedaan pengaruh ukuran perusahaan, profitabilitas, likuiditas, leverage, dan umur listing terhadap pengungkapan Internet Financial Reporting antara Indonesia dan Malaysia diterima.

\section{KETERBATASAN PENELITIAN}

Penelitian yang dilakukan tidak terlepas dari keterbatasan, adapun beberapa keterbatasan penelitian antara lain penelitian ini hanya mengambil sampel dari perusahaan manufaktur sehingga belum dapat mencerminkan semua sektor perusahaan. Sampel dalam penelitian ini menggunakan periode pengamatan yang pendek, yaitu hanya 3 tahun sehingga kurang luas jangkauan periode pengamatannya. Hasil pengolahan data masih menunjukkan ada beberapa variabel yang tidak berdistribusi normal, sehingga beberapa sampel outlier yang harus dibuang. Penelitian ini hanya menggunakan tiga variabel independen, sedangkan masih ada variabel-variabel independen lain yang berpengaruh terhadap kebijakan hutang.

\section{KESIMPULAN}

Berdasarkan analisis dan pengujian data dalam penelitian ini, dapat ditarik kesimpulan sebagai berikut: Ukuran perusahaan berpengaruh positif terhadap pengungkapan IFR di Indonesia dan Malaysia. Profitabilitas tidak berpengaruh terhadap pengungkapan IFR di Indonesia, sedangkan di Malaysia berpengaruh positif. Likuditas tidak berpengaruh terhadap pengungkapan IFR di Indonesia dan Malaysia. Leverage tidak berpengaruh terhadap pengungkapan IFR di Indonesia dan Malaysia. Umur listing tidak berpengaruh terhadap pengungkapan IFR di Indonesia dan Malaysia. Terdapat perbedaan pengungkapan IFR di Indonesia dan Malaysia. Terdapat perbedaan pengaruh ukuran perusahaan, profitabilitas, likuiditas, leverage, dan umur listing terhadap pengungkapan IFR di Indonesia dan Malaysia.

Berdasarkan hasil penelitian ini terdapat beberapa saran untuk perbaikan penelitian kedepanya sebagai berikut: Penelitian selanjutnya diharapkan dapat memperpanjang periode penelitian untuk mendapatkan hasil yang lebih akurat, dapat menggunakan seluruh jenis perusahaan tidak hanya terpaut pada perusahaan manufaktur agar dapat menggambarkan praktik pengungkapan IFR secara keseluruhan. Penelitian selanjutnya diharapkan dapat membandingkan dengan negara lain yang masih serumpun (studi komparatif), serta memasukkan variabel lain yang mungkin berpengaruh terhadap pengungkapan IFR.

\section{DAFTAR PUSTAKA}

Agusto, K. E. (2017). Analisis Karakteristik Perusahaan Terhadap Luas Pengungkapan Internet Financial Reporting. Jurnal Akuntansi, Universitas Muhammadiyah Yogyakarta.

Akbar, D. A. (2014). Analisis Faktor yang Mempengaruhi Pengungkapan Laporan Perusahaan Berbasis Website (Doctoral dissertation, Fakultas Ekonomika dan Bisnis)

Akbar, D. A., Daljono, D. (2014). Analisis Faktor yang Mempengaruhi Pengungkapan Laporan Perusahaan Berbasis Website (Doctoral dissertation, Fakultas Ekonomika dan Bisnis).

Alarussi, A. S., \& Shamkhi, D. (2016). Company Characteristics, Dominant Personalities In Board Committees And Internet Financial Disclosures By Malaysian Listed Companies.

Alarussi, A. S., Selamat, M. H., \& Mohd Hanefah, M. (2011). The determinants of internet financial disclosure: The perspective of Malaysian listed companies. International Journal of Management Studies (IJMS), 18(1), 1-29. 
Almilia, L. S. \& Budisusetyo, S. (2009). Corporate Internet Reporting: An Indonesia Example. The I" Parahyangan International Accounting \& Business Conference.

Almilia, L. S. (2008). Faktor-faktor yang Mempengaruhi Pengungkapan Sukarela Internet Financial and Sustainability Reporting. Jurnal Akuntansi dan Auditing Indonesia, 12(2).

Alwi, A. (2015). Pengaruh Leverage, Reputasi Auditor, Umur Listing, dan Kepemilikan Asing terhadap Praktik Internet Financial Reporting. Jurnal Ilmiah Universitas Bakrie, 3(02).

Ashbaugh, H., Johnstone, K.M., \& Warfield, T.D., (1999). Corporate Reporting on the Internet. Accounting Horizons, 13 (3), 241 - 257.

Asmoro, P. S. (2011). Pengaruh Karakteristik Perusahaan dan Corporate Governance terhadap Pengungkapan Informasi Melalui Website dan Implikasinya terhadap Nilai Perusahaan (Studi pada Perusahaan Publik di Bursa Efek Indonesia). Tesis. Malang: Universitas Brawijaya.

Asprilia, R. (2016). Faktor-Faktor Yang Memengaruhi Pengungkapan Informasi Melalui Website Perusahaan Yang Terdaftar Di Bursa Efek Indonesia (Doctoral dissertation, Fakultas Ekonomika dan Bisnis).

Azaria, A., \& Achyani, F. (2015). Faktor-Faktor yang Mempengaruhi Tingkat Keluasan Pengungkapan Informasi dalam Laporan Tahunan, 93-103.

Budyanto, T. (2017). Pengaruh Ukuran Perusahaan, Umur Listing Perusahaan, Kepemilikan Dispersi, Profitabilitas, Ukuran Dewan Komisaris, Dan Leverage Terhadap Luas Pengungkapan Corporate Governance Pada Perusahaan Manufaktur Yang Terdaftar Di Bursa Efek Indonesia.

Devi, I. A. S., \& Suardana, K. A. (2014). Pengaruh Ukuran Perusahaan, Likuiditas, Leverage dan Status Perusahaan pada Kelengkapan Pengungkapan Laporan Keuangan, Vol. 83, h. 47

Ghozali, I. 2007. Analisis multivariate dengan Program SPSS. Semarang: Badan Penerbit Universitas Diponegoro.

Hamidah, H., Wicaksono, A., \& Ahmad, G. N. (2017). The Effect Of Firm Performance, Leverage, Firm Size, And Firm Growth On Agency Cost Of Trading Company In Indonesia, Malaysia, And Thailand: Research Period Of 2009-2013. JRMSI-Jurnal Riset Manajemen Sains Indonesia, 8(1), 119-138.

Handayani, E., \& Almilia, L. S. (2013). Internet Financial Reporting: Studi Komparasi Perusahaan Manufaktur yang Terdaftar di Bursa Efek Indonesia dan Bursa Efek Malaysia. Jurnal Bisnis dan Ekonomi, 20(2).

Handoko, M., dan Fuad, F. U. A. D. (2013). Anteseden dan konsekuensi Tingkat Pengungkapan Informasi Keuangan berbasis internet: Peran Moderasi Kinerja Keuangan (Doctoral dissertation, Fakultas Ekonomika dan Bisnis).

Hanifa, M. H., \& Rashid, H. M. A. (2005). The determinants of voluntary disclosures in Malaysia: The case of internet financial reporting. UNITAR e-Journal, 2(1), 22-42.

Hilmi, U., dan Ali, S. (2008). Analisis faktor-faktor yang mempengaruhi ketepatan waktu penyampaian laporan keuangan. Simposium Nasional Akuntansi XI Ikatan Akuntan Indonesia. $h, 1-22$.

Homayoun, S., \& Rahman, R. A. (2010). Determinants of web-based corporate reporting among top public listed companies in Malaysia. International journal of Arts and sciences, 3(13), 187-212.

http://www.bursamalaysia.com/market/listed-companies/listing-on-bursa-malaysia/listing-criteria/ diakses pada tanggal 16 Oktober 2017 pukul 16:49 WIB

http://www.internetworldstats.com diakses pada tanggal 21 Mei 2017 pukul 13:29 WIB

Insani, T. D., \& Suprayogi, N. (2017). Internet Financial Reporting: Studi Komparasi Bank Umum Syariah di Indonesia dan Malaysia. Jurnal Ekonomi Syariah Teori dan Terapan, 3(11), 886.

Jensen, M. C., \& Meckling, W. H. (1976). Theory of the firm: Managerial behavior, agency costs and ownership structure. Journal of Financial Economics, 3(4), 305-360.

Kartika, I., \& Puspa, A. M. (2013). Karakteristik Perusahaan Sebagai Determinan Internet Financial and Sustainability Reporting. Jurnal Keuangan dan Perbankan, 17(2), 181-191. 
Kusumawardani, A. (2011). Analisis Faktor-Faktor yang Mempengaruhi Pelaporan Keuangan Melalui Internet (Internet Financial Reporting) dalam Website Perusahaan. Skripsi Program Sarjana Fakultas Ekonomi Universitas Diponegoro.

Lai, S. C., C. Lin, H. Li, \& F. H. Wu. (2010). An Empirical Study of the Impact of Internet Financial Reporting on Stock Prices. The International Journal of Digital Accounting Research 10: 126.

Leonardi, L. A., Purbandari, T., \& Handayani, D. (2014). Pengaruh Ukuran Perusahaan, Return on Asset (ROA), Leverage, dan Umur Listing terhadap Pengungkapan Internet Financial and Sustainability Reporting (IFSR) pada Perusahaan Manufaktur yang Listed di Bursa Efek Indonesia (BEI) tahun 2009-2012. Jurnal Riset Manajemen dan Akuntansi (JRMA), 2(2), 6880 .

Lestari H. S. \& Chariri, A. (2007). Analisis Faktor-faktor yang Mempengaruhi Pelaporan Keuangan Melalui Internet (Internet Financial Reporting) dalam Website Perusahaan. Working Paper Fakultas Ekonomi Universitas Diponegoro, Semarang.

Marston, C. \& Polei, A. (2004). Corporate reporting on the internet by German companies. International Journal of Accounting Information Systems, 5, 285-311.

Na'im, A., \& Rakhman, F. (2000). Analisis Hubungan Antara Kelengkapan Pengungkapan Laporan Keuangan Dengan Struktur Modal dan Tipe Kepemilikan Perusahaan. Jurnal Ekonomi dan Bisnis Indonesia. 15 (1), 7-82.

Narsa, I. M., \& Pratiwi, F. F. (2017). Internet Financial Reporting, Pengungkapan Informasi Website, Luas Lingkup Pelaporan Internet, Dan Nilai Perusahaan. Ekuitas (Jurnal Ekonomi dan Keuangan), 18(2), 259-273.

Nazaruddin, I., \& Basuki, A. T. (2015). Analisis Statistik dengan SPSS. Yogyakarta: Danisa Media.

Nurhadianto, T. (2014). Pengaruh Karakteristik Perusahaan dan Mekanisme Corporate Governance Terhadap Luas Pengungkapan Internet Financial Reporting. Jurnal Akuntansi, Universitas Muhammadiyah Yogyakarta.

Oyelere, P., Lasward, F. \& Fisher, R. (2003). Determinants of Internet Financial Reporting by New Zealand Companies. Journal of International Financial Management and Accounting, 14 (1), 26-63.

Pranoto, K. P. T. (2015). Pengaruh Likuiditas, Profitabilitas, Ukuran Perusahaan, Jenis Industri, Leverage, Dan Umur Listing Terhadap Pelaporan Keuangan Melalui Internet Financial Reporting (Doctoral dissertation, STIE Perbanas Surabaya).

Prasetya, M., \& Irwandi, S. A. (2012). Faktor-faktor yang Mempengaruhi Pelaporan Keuangan Melalui Internet (Internet Financial Reporting) pada Perusahaan Manufaktur di Bursa Efek Indonesia. The Indonesian Accounting Review, 2(2), 151-158.

Pubandani, E., \& Restuti, M. M. D. (2013). Faktor-Faktor Yang Mempengaruhi Pengungkapan Sukarela Melalui Internet Pada Perusahaan Yang Terdaftar di BEI Tahun 2012. Sustainable Competitive Advantage (SCA), 3(1).

Puspitaningrum, A., \& Prastiwi, A. (2012). Pengaruh Karakteristik Perusahaan Terhadap Pengungkapan Internet Financial and Sustainability Reporting (IFSR) (Studi Pada Perusahaan Yang Terdaftar Di Bursa Efek Indonesia). Jurnal Ilmiah Mahasiswa Feb, 1(2).

Ramadhan, N. N. (2014). Analisis Faktor Yang Mempengaruhi Luas Pengungkapan Sosial Dan Lingkungan Melalui Website Perusahaan (Doctoral dissertation, Fakultas Ekonomika dan Bisnis).

Reskino, \& Sinaga, N. N. J. (2016). Kajian Empiris Internet Financial Reporting Dan Praktek Pengungkapan. Media Riset Akuntansi, Auditing dan Informasi, 16(2), 85-106.

Rozak, A. (2012). Pengaruh Tingkat Profitabilitas, Ukuran Perusahaan, Kepemilikan Saham Oleh Publik, Leverage dan Kelompok Industri Terhadap Tingkat Internet Financial Reporting (IFR). Jurnal Computech \& Bisnis, 6(2), 101-112.

Santosa, R. I. (2015). Pengaruh Karakteristik Perusahaan Dan Mekanisme Corporate Governance Terhadap Pengungkapan Internet Financial Reporting (Studi Empiris Pada Perusahaan yang Terdaftar di Daftar Efek Syariah). Jurnal Akuntansi, Universitas Muhammadiyah Yogyakarta. 
Septiarsi, N. M., \& Prastiwi, A. (2013). Analisis Faktor-Faktor Yang Mempengaruhi Pengungkapan Pelaporan Keuangan Melalui Internet dalam Website Perusahaan (Doctoral dissertation, Fakultas Ekonomika dan Bisnis).

Siagian, G. E., \& Ghozali, I. (2012). Pengaruh Struktur dan Aktivitas Good Corpoarate Governance Terhadap Luas Pengungkapan Informasi Strategis Secara Sukarela Pada Website Perusahaan Yang Terdaftar Dalam Bursa Efek Indonesia. Diponegoro Journal of Accounting, 1, 1-11.

Soepriyanto, G., \& Dustinova. (2012). Faktor Penentu Pengungkapan Informasi Laporan Keuangan Melalui Laman Internet: Studi Empiris pada Perusahaan yang Terdaftar, 3(1), 286-301.

Sudarmadji \& Sularto. (2007). Pengaruh Ukuran Perusahaan, Profitabilitas, Leverage, dan Tipe Kepemilikan Perusahaan terhadap Luas Voluntary Disclosure Laporan Keuangan Tahunan. Jurnal Akuntansi Universitas Gunadarma.

Sulistyanto, H. R., \& Nugrahanti, Y. W. (2013). Analisis perbedaan ketepatan waktu internet financial reporting pada perusahaan manufaktur yang terdaftar di BEI. Jurnal Dinamika Akuntansi, 5(2).

Susanto, Y. K., \& Lukito, Y. P. (2015). Faktor-Faktor yang Memengaruhi Pengungkapan Sukarela Internet Financial and Sustainability Reporting. Jurnal Keuangan dan Perbankan, 17(1), 6170 .

Turmin, S. Z., Hamid, F. A., \& Ghazali, N. A. M. (2015). Corporate Internet Reporting in Emerging Economic Countries: The Malaysian Perspective. Pertanika Journal of Social Sciences \& Humanities, 23.

Turmin, S., Hamid, F. A., \& Ghazali, N. A. M. (2014). Web-based business reporting: The influences drivers. Proceeding of the Social Sciences Research ICSSR, 9-10.

Watts, Ross L. \& Zimmerman, Jerold L. (1986). Positive Accounting Theory. Prentice Hall: International Edition

Wolk, H. I., Michael G. T., \& James L. D. (2008). Accounting Theory: A Conceptual and Institutional Approach. South- Western College Publishing.

Yeye, S. (2011). Reaksi Signal Rasio Profitabilitas dan Rasio Solvabilitas Terhadap Return Saham Perusahaan. Jurnal Dinamika Keuangan dan Perbankan. 3(1), 17-37. 